\title{
Práticas pedagógicas para a inclusão e a diversidade
}

Pedagogical practices for inclusion and diversity

Jessica de Brito*

Rosimeire Maria Orlando**

\section{CUNHA, E. (Org.). Práticas pedagógicas para a inclusão e a diversidade.}

Rio de Janeiro: WAK Editora, 2011.

A participação das pessoas com necessidades educacionais especiais (NEE), na sociedade, é recente, principalmente por ter sido levado em conta pressupostos arraigados sobre anormalidade e deficiência ao longo da história da humanidade. Desde longe, do período da era clássica aos tempos atuais, muitas foram as concepçóes cultivadas sobre as pessoas com deficiência, bem como de seu papel na sociedade. (JANNUZZI, 2006)

Em consequência dessas concepçôes, o processo de direcionamento das pessoas com NEE à educação lentamente vem sendo conquistado, juntamente com o da população em geral, e, partindo deste fato, o livro Práticas pedagógicas para inclusão e a diversidade, organizado pelo autor Eugênio Cunha - professor, pesquisador e integrante do grupo de pesquisa em Políticas Públicas de Educação da Universidade Federal Fluminense - GRUPPE/UFF/CNPq - reúne experiências e práticas ocorridas em seu cotidiano docente sobre alunos com NEE. A obra é constituída, de modo geral, pela importância da educação inclusiva, sendo esta temática hoje em dia bastante discutida na academia.

Organizado em onze capítulos, o livro tece reflexôes sobre a diversidade na escola e na sociedade, currículo inclusivo e a estimulação dos alunos com NEE, sobre as etapas da atuação docente, bem como sobre a importância da família no processo de inclusão escolar e social.

No âmbito da historicidade, no primeiro capítulo, intitulado "Um pouco sobre diversidade, escola e inclusão", Eugênio Cunha utiliza-se de uma linha do tempo para explicar como a educação inclusiva esteve/está presente em todas as épocas e lugares, enfocando que, mesmo para as pessoas com NEE, a escola é lugar de suma importância para o desenvolvimento social e cognitivo delas, capaz, por sua essência, de cumprir a mais elevada destinação social do saber: o aprendizado do saber sistematizado.

\footnotetext{
* Mestranda em Educação pela Universidade Federal de São Carlos. São Carlos, São Paulo, Brasil.
}

** Professora doutora da Universidade Federal de São Carlos. São Carlos, São Paulo, Brasil. 
Quando o assunto é currículo escolar inclusivo, o autor, em seu segundo capítulo, intitulado "Um currículo inclusivo", ressalta que este deve estar articulado com as dinâmicas sociais provenientes dos educandos, ter como ponto de partida o cotidiano do aluno. Além disso, ressalta a importância da construção de um currículo com a participação da equipe escolar, abrangendo desde professores até gestores e familiares, ou seja, uma equipe que efetive a funcionalidade do currículo para a vida escolar e social do aluno.

No terceiro capítulo, intitulado "O que estimular no aluno?", o autor destaca as habilidades que todos os alunos, incluindo aqueles com necessidades especiais, devem aprender dentro da escola, sendo elas: Afetividade; Socializaçáo e ludicidade; Linguagem e comunicação; Educação Psicomotora; Música e Arte; e contar com uma boa alimentação. A par de tais habilidades, o autor acredita que o professor poderá atuar, de forma eficaz, para superar tanto as dificuldades de si mesmo como a de seus alunos com NEE.

Em seu quarto capítulo, “Teoria e prática: utilizando ideias pedagógicas para educar", discute a questão de que a escola contemporânea náo pode ser inflexível e estanque, já que a inteligência dinamicamente está em constante adaptação e, por meio de estímulos, mune-se de habilidades emocionais, cognitivas e criativas. Por isso, os professores necessitam tanto do conhecimento que adquirem em razáo do exercício da prática docente quanto das diversas teorias pedagógicas que dão suporte ao trabalho. Nesse contexto, Eugênio Cunha póe em destaque as teorias de Piaget, Vygotsky, Ausubel e Paulo Freire.

Nos capítulos quinto e sexto, intitulados, respectivamente, "Estágios da aprendizagem discente" e "Etapas da atuação docente", o autor revela-nos que há quatro estágios da aprendizagem, sendo o primeiro o estágio diretivo - que depende invariavelmente da presença do professor; o autônomo - em que o aluno adquire a capacidade de aprender novas habilidades por iniciativa própria; o criativo - que abarca modificaçôes operadas pelo aprendiz, que vão desde executar novas tarefas até manusear materiais e, por ultimo, o estágio colaborativo - com produçóes individuais ou em grupo, socializando o saber produzido, tanto pelo educando quanto pelo educador. Já em relação às etapas da atuação docente, o autor enfoca três etapas do trabalho pedagógico, sendo a primeira a observaçáo, que é uma das etapas do método científico, em que os elementos observados são catalogados e organizados para, posteriormente, serem analisados. A segunda etapa é a avaliação, sendo esta objetiva, ou seja, que compreende o comportamento do aluno diante dos instrumentos de ensino e aprendizagem. Esta etapa torna-se, desse modo, um mecanismo de melhoria nas decisões que virão a seguir, pois está direcionada à aprendizagem discente. A última etapa é a mediação, que é aquela na qual o professor utiliza-se de atividades que permitirão o melhor desenvolvimento do aprendente, ou seja, o que mais interessa a este.

Sobre "O que é preciso saber? Um olhar sobre algumas necessidades especiais mais comuns na escola”, o sétimo capítulo ressalta algumas observaçóes que podem auxiliar os professores na sua prática. Discute temas importantes como o Autismo, a Síndrome de Down, Transtorno de Déficit de Atenção e Hiperatividade (TDHA), 
Transtornos Emocionais, dentre outras. Colabora sobremaneira ao trazer à tona algumas atividades interessantes a fim de aguçar, além da motricidade e do cognitivo, a criatividade e a afetividade de seus alunos com e sem NEE.

Com tais considerações, leva o leitor a concluir que a família sempre deve estar presente na escola para que a inclusão seja efetiva, já que a tríade escola, família e sociedade favorece a formação de todos os alunos. Os capítulos oitavo e nono, intitulados "Família e escola" e "O afeto e suas três dimensóes: pessoal, social e pedagógica", dá enfoque à emoção como uma das forças motrizes do processo de inclusão do aluno com NEE na escola.

Para finalizar, os dois últimos capítulos, décimo e décimo primeiro, respectivamente com os títulos "Breve histórico de políticas inclusivas" e "Propostas de atividades", Eugênio Cunha apresenta um trajeto das políticas destinadas à educação especial no Brasil, propondo algumas atividades práticas que poderiam ser apropriadas pelos professores, bastando, para tanto, utilizar-se de criatividade para que tomem corpo e, assim, contribuam para a prática inclusiva.

As discussōes encontradas nesses textos revelam ao leitor uma visão mais clara sobre a Educação Inclusiva, enfatizando-lhe a importância para o processo de inclusão de alunos com NEE dentro da escola.

Enfim, ao recebermos alunos com NEE em nossa sala de aula, perguntamos: Como educá-los? Como incluí-los? Em seu livro, Eugênio Cunha aponta os elementos que podem colaborar na busca de respostas para tais perguntas nitidamente importantes na área educacional. As discussóes levantadas no livro proporcionam ao leitor inúmeras reflexões, sobretudo em relação às práticas pedagógicas que devem ser consideradas para esse alunado e, também, sobre os conteúdos curriculares a serem utilizados para ele, ressaltando os anseios e desejos desses sujeitos que, assim como todos, têm o direito à educação e à cidadania.

\section{Correspondência}

Jessica de Brito - Universidade Federal de São Carlos, Centro de Educação e Ciências Humanas, Departamento de Educaçáo. Rodovia Washington Luis, KM 235. CEP: 13565-905, Monjoalinho - São Carlos, São Paulo, Brasil.

E-mail: debrito_jessica@yahoo.com.br - meiremorlando@gmail.com

Recebido em 15 de fevereiro de 2014

Aprovado em 05 de agosto de 2014 
